\title{
Functional and morphological characteristics of the first corpus luteum formed after parturition in ewes*
}

\author{
T. D. Braden $\dagger$, H. R. Sawyer and G. D. Niswender \\ Animal Reproduction Laboratory, Department of Physiology, Colorado State University, \\ Fort Collins, Colorado 80523, USA
}

\begin{abstract}
Summary. The ability of sheep luteal cells from the first corpus luteum formed after parturition (Group F) to secrete progesterone in the presence or absence of LH was compared with that of luteal cells obtained from normal cyclic ewes (Group C). Luteal concentrations of receptors for LH and prostaglandins (PG) F-2 $\alpha$ (PGF-2 $\alpha$ ) and the cellular composition of corpora lutea from Groups $F$ and $C$ were also compared. Luteal cells from Group $F$ secreted less progesterone in either the presence or absence of LH $(P<0.01)$. There was no difference in the number of receptors for LH or PGF$2 \alpha$ per luteal cell between Groups $\mathrm{F}$ and $\mathrm{C}(P>0 \cdot 1)$, nor was there a difference in the number of large or small steroidogenic luteal cells $(P>0 \cdot 1)$. It was concluded that, if short-lived corpora lutea are insensitive to gonadotrophins, this response is not mediated by decreased numbers of receptors for LH. In addition, if the first corpus luteum formed post partum in ewes is more sensitive to the luteolytic effects of PGF-2 $\alpha$, this effect is not mediated by an increased number of receptors for PGF-2 $\alpha$ or an increased proportion of PGF- $2 \alpha$-sensitive large luteal cells.
\end{abstract}

Keywords: corpora lutea; post partum; sheep; LH receptors; PGF-2 $\alpha$ receptors

\section{Introduction}

The first corpus luteum formed after parturition in cattle and sheep is frequently short-lived (Lamming et al., 1981; Manns et al., 1983; Wise et al., 1986). Short-lived corpora lutea also occur at puberty (Gonzalez-Padilla et al., 1975; Berardinelli et al., 1979, 1980) and at the beginning of the breeding season in ewes (Yuthasastrakosol et al., 1975). Several possibilities exist to explain regression of short-lived corpora lutea including: (1) inadequate gonadotrophic support; (2) inability of short-lived corpora lutea to respond to gonadotrophins; (3) premature release of luteolysin; and/or (4) an enhanced sensitivity of short-lived corpora lutea to the luteolytic signal.

The first corpus luteum formed after parturition does not regress prematurely in ewes and cows hysterectomized after parturition (Schirar \& Martinet, 1982; Copelin et al., 1987). The uterus is therefore required for early regression of short-lived corpora lutea and regression appears to be an active process. Additionally, a lack of gonadotrophic support does not appear to be the primary causative factor for early regression since Carruthers et al. (1986) could not prevent regression of short-lived corpora lutea by administration of human chorionic gonadotrophin. Premature release of prostaglandins (PG) has been implicated in the regression of short-lived corpora lutea (Thatcher et al., 1980; Troxel \& Kesler, 1984a, b). Troxel \& Kesler (1984a) administered indomethacin, a PG synthesis inhibitor, to cows expected to have a short-lived corpus luteum and were able to extend the life-span of these corpora lutea. However, during regression of short-lived corpora lutea in

*Reprint requests to Dr G. D. Niswender.

$\nmid$ Present address: Department of Pharmacology, University of Iowa, Iowa City, IA 52242, USA. 
cows, Manns et al. (1983) did not observe pulses of 13,14-dihydro-15-keto-PGF-2 $\alpha$ similar to those expected to occur during normal regression. Together, these data can be interpreted to indicate a role for the uterus and PGF- $2 \alpha$ in causing regression of short-lived corpora lutea, although it does not appear that serum concentrations of PGF- $2 \alpha$ are as high as those observed during luteolysis in normal cyclic animals. A short luteal phase may therefore be the result of a corpus luteum that is hypersensitive to low levels of PGF- $2 \alpha$.

The corpora lutea of ewes and cows are composed of two steroidogenic cell types, termed large and small luteal cells (Donaldson \& Hansel, 1965; Fitz et al., 1982). In sheep, most of the luteal receptors for PGF-2 $\alpha$ are localized on large steroidogenic luteal cells (Fitz et al., 1982). Therefore, it appears that the luteolytic process may be mediated via large luteal cells which may be derived from granulosa cells of the preovulatory follicle (Donaldson \& Hansel, 1965; McClellan et al., 1975; Alila \& Hansel, 1984). The first preovulatory follicle formed after parturition in cows contains approximately twice the number of granulosa cells as are in subsequently formed preovulatory follicles (Braden et al., 1989). Therefore, if the greater number of granulosa cells in the preovulatory follicle leads to formation of a corpus luteum with an unusually high proportion of large luteal cells, that corpus luteum would be expected to have an enhanced sensitivity to the luteolytic effects of PGF-2 $\alpha$. A second mechanism for enhanced sensitivity to PGF-2 $\alpha$ would be an increase in the number of receptors for PGF-2 $\alpha$ on specific (large) cells. In the present study, both possibilities were tested.

\section{Materials and Methods}

Tissues. Corpora lutea were collected from 10 post-partum ewes after the first post-partum preovulatory surge of LH and from 10 ewes that were normally cycling. To obtain post-partum ewes, anoestrous Western range ewes were treated with progestagen implants for 9 days in April or May. Upon removal of the implants, ewes were injected subcutaneously with 350 i.u. PMSG to stimulate follicular development and ovulation. These ewes were then mated to fertile rams which allowed lambs to be born during the breeding season (September and October), when post-partum anoestrus would not be confounded by seasonal anoestrus. Lambs were allowed to suck normally after birth.

To detect the preovulatory surge of $\mathrm{LH}$ and allow accurate timing for the collection of tissue, blood samples were obtained from each ewe at 6 -h intervals beginning 7 days after parturition. Blood samples were allowed to clot at room temperature for $6 \mathrm{~h}$, stored at $4^{\circ} \mathrm{C}$ and the following day serum was collected. A rapid radioimmunoassay for LH was performed using $200 \mu \mathrm{l} \mathrm{serum,} 100 \mu \mathrm{l}^{125}$ I-labelled oLH, $200 \mu \mathrm{l}$ anti-ovine LH serum (Niswender et al., 1969) and $500 \mu \mathrm{l}$ phosphate-buffered saline containing $0.1 \%$ gelatin (PBS-gel; $0.01 \mathrm{M}-\mathrm{NaPO}_{4}, 0.14 \mathrm{M}-\mathrm{NaCl}, 0.22 \mathrm{~mm}$ merthiolate, $0.1 \%(\mathrm{w} / \mathrm{v})$ gelatin; $\mathrm{pH} 7.0$ ) and were incubated for $8 \mathrm{~h}$ at $4^{\circ} \mathrm{C}$. The $200 \mu \mathrm{l}$ of second antibody (goat antirabbit immunoglobulin) were added to each assay tube and they were incubated for 12 additional hours. Hormone bound to antibody was separated from free hormone by centrifugation at $800 \mathrm{~g}$ for $30 \mathrm{~min}$ at $4^{\circ} \mathrm{C}$ and the radioactivity associated with the bound hormone was quantified using an Isodata 20/20 gamma counter. This assay allowed detection of LH concentrations associated with a preovulatory surge. Based on preliminary studies in normal cyclic ewes,

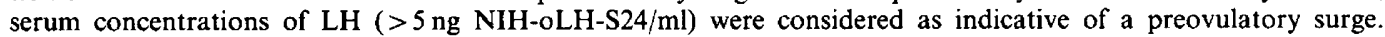
Typically, two sequential samples contained $>5 \mathrm{ng} \mathrm{LH} / \mathrm{ml}$.

The day on which the first preovulatory surge of $\mathbf{L H}$ occurred after parturition was designated Day 0 . Corpora lutea were collected aseptically from 5 ewes each on Days 4 and 7 via mid-ventral incision while ewes were under pentobarbitone anaesthesia (Group F). Corpora lutea were also collected from 5 normal cyclic ewes on Days 4 and 7 after the preovulatory surge of $\mathrm{LH}$ (Group C). The volume and mass of each corpus luteum were determined (Farin $e t$ al., 1986) and $0.5 \mathrm{~mm}$ thick slices were made with a Stadie Riggs hand-held microtome. A single slice from the centre of each corpus luteum obtained from ewes on Day 4 was processed for electron microscopy and the remaining tissue was dispersed with collagenase (Simmons et al., 1976). Since 6 of 9 of the corpora lutea collected from Group F on Day 7 were regressing, based on a pale, white appearance and reduced size, no attempt was made to assess them morphologically. Only 2 corpora lutea collected from Group F ewes on Day 7 contained enough tissue for all procedures. Therefore, 4 additional post-partum ewes were treated as described above but quantification of receptors for PGF-2 $\alpha$ was the only procedure performed (total $N=6$ ). In addition, corpora lutea were collected from 3 additional normal cyclic ewes on Day 7 for analysis of the concentration of PGF- $2 \alpha$ receptors (total $N=8$ ).

After dissociation, cells were washed twice with $10 \mathrm{ml}$ Medium 199. A sample of this suspension was placed in a haemocytometer and the number of luteal cells per unit volume was determined. Progesterone secretion was estimated by placing 25000 total luteal cells (excluding red blood cells) in $1 \mathrm{ml}$ Medium 199 with or without $100 \mathrm{ng} \mathrm{oLH} / \mathrm{ml}$ for $6 \mathrm{~h}$ at $37^{\circ} \mathrm{C}$ in a shaking water bath. After incubation, medium and cells were separated and rapidly frozen. The quantity of progesterone in the media was measured by radioimmunoassay (Niswender, 1973). The limit of detection for progesterone in media was $25 \mathrm{pg}$ and the intra-assay coefficient of variation was less than $10 \%$. 
Quantitation of receptors for PGF-2a. The concentration of receptors for PGF-2a in luteal tissue was determined by the standard curve technique. This technique allows accurate quantification of receptors and estimation of affinity of hormone binding to receptor, and its major advantage is that it requires much less tissue than does Scatchard analysis. This procedure has previously been shown to be valid for quantification of receptors for gonadotrophinreleasing hormone (Nett et al., 1981), luteinizing hormone and follicle-stimulating hormone (Braden et al., 1986).

Radiolabelled PGF-2 $\alpha\left(\left[5,6,8,9,11,12,14,15(\mathrm{n})-{ }^{3} \mathrm{H}\right] \mathrm{PGF}-2 \alpha\right.$; sp. act. $\left.180 \mathrm{Ci} / \mathrm{mmol}\right)$ was purchased from Amersham Corp. (Arlington Heights, IL, USA). The assay buffer was $10 \mathrm{~mm}$-Tris- $\mathrm{HCl}, \mathrm{ImM}-\mathrm{CaCl}_{2}, 1 \mathrm{~mm}-\mathrm{MgCl}_{2}$ and $0 \cdot 1 \%$ $(\mathrm{w} / \mathrm{v})$ bovine serum albumin $(\mathrm{pH} 7 \cdot 4)$. Membranes prepared from ovine corpora lutea obtained during the mid-luteal phase of the oestrous cycle were used for the standard membrane preparation. Each assay included: (1) a standard curve using the standard membrane preparation; (2) Scatchard analysis (Scatchard, 1949) to determine the concentration of PGF- $2 \alpha$ receptors in the standard membrane preparation; and (3) incubation of membranes from each tissue sample with the same amount of $\left[^{3} \mathrm{H}\right] \mathrm{PGF}-2 \alpha$ used for the standard curve.

Corpora lutea were collected from superovulated ewes on Day 10 of the oestrous cycle, decapsulated and homoge-

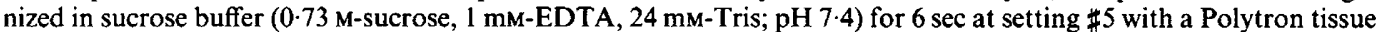
homogenizer. The tissue was further homogenized with 15 strokes in a $15 \mathrm{ml}$ Dounce homogenizer. Plasma membranes were isolated by centrifugation of the whole homogenate at $100 \mathrm{~g}$ for $5 \mathrm{~min}$ at $4^{\circ} \mathrm{C}$. The supernatant fraction was then centrifuged at $30000 \mathrm{~g}$ for $15 \mathrm{~min}$ at $4^{\circ} \mathrm{C}$ and the pellet resuspended in assay buffer $\left(10 \mathrm{mM}-\mathrm{Tris}, 1 \mathrm{mM}-\mathrm{CaCl}_{2}\right.$, $1 \mathrm{mM}-\mathrm{MgCl}_{2}, 0 \cdot 1 \%$ (w/v) bovine serum albumin; $\left.\mathrm{pH} 7 \cdot 4\right)$.

The number of receptors for PGF-2 $\alpha$ was determined in the pool of standard membrane by Scatchard analysis (Scatchard, 1949) with various amounts of PGF-2 $\alpha$ (0 to $300 \mathrm{ng} /$ tube) contained in $100 \mu$ assay buffer. Approximately 50000 c.p.m. $(0 \cdot 027 \mathrm{ng})$ of $\left[{ }^{3} \mathrm{H}\right] \mathrm{PGF}-2 \alpha\left(\left[5,6,8,9,11,12,14,15(\mathrm{n}){ }^{3} \mathrm{H}\right] \mathrm{PGF}-2 \alpha ;\right.$ Amersham Corp. $)$ were added to each tube in $100 \mu \mathrm{l}$ volume. Assay buffer containing excess PGF- $2 \alpha(500 \mathrm{ng})$ was added to separate tubes at each tissue level in $100 \mu \mathrm{l}$ volume to determine non-specific binding. Then $100 \mu \mathrm{l}$ containing 30 or $60 \mathrm{mg}$ tissue membrane equivalents (two separate Scatchard analyses) were added for a total volume of $300 \mu \mathrm{l}$.

The standard curve was generated by incubating different quantities of the standard membrane preparation $(1,5$, $10,30,60,70,90,100,300$ and $500 \mathrm{mg} /$ tube) with a constant amount of radiolabelled PGF- $2 \alpha$ (50000 c.p.m.; $0.027 \mathrm{ng}$ ). Samples of unknown receptor concentration were incubated with the same level of radiolabelled hormone as the standard membrane preparation. The reaction mixtures $(300 \mu \mathrm{l}$ total volume) were incubated for $6 \mathrm{~h}$ at room temperature in $12 \times 75 \mathrm{~mm}$ polypropylene tubes. Hormone bound to receptor was separated from free hormone by centrifugation $\left(30000 \mathrm{~g} ; 4^{\circ} \mathrm{C} ; 15 \mathrm{~min}\right)$. Following centrifugation, $4 \mathrm{ml}$ assay buffer were slowly added to each tube and immediately aspirated. Then $2 \mathrm{ml}$ scintillation cocktail containing Triton X-100 (12 g Omnifluor; 11 Triton X-100; 21 toluene) were added to each tube and incubated overnight to solubilize the membrane pellet. An additional $2 \mathrm{ml}$ cocktail were added to each tube and the total volume transferred to a glass mini-vial and the associated radioactivity quantified.

The concentration of receptors in sample tissue was determined by direct comparison to the standard curve. For each sample, $1 \times 10^{6}$ luteal cells were homogenized in duplicate and assayed in a volume of $100 \mu$. Non-specific binding was evaluated at each tissue concentration with the addition of $500 \mathrm{ng}$ PGF-2 $\alpha$ to one-half of the tubes. The resulting data were transformed to logit $v s \log$ to linearize the data. Data obtained from incubation of sample tissue were then compared to the linearized plot. Under our assay conditions, maximal binding of the $\left[{ }^{3} \mathrm{H}\right]$ prostaglandins was approximately $30 \%$ while non-specific binding was always less than $9 \%$.

Data regarding the ability of arachidonic acid and several prostaglandins to inhibit the binding of $\left.{ }^{3} \mathrm{H}\right] \mathrm{PGF}-2 \alpha$ to ovine luteal membranes are shown in Fig. 1. The amount of PGE-2 required to inhibit the binding of $\left[{ }^{3} \mathrm{H}\right] \mathrm{PGF}-2 \alpha$ by $50 \%$ was approximately $100 \mathrm{ng}$ compared to $3 \mathrm{ng}$ PGF- $2 \alpha$ (cross-reactivity $3 \%$ ). Much higher amounts of PGE-1 and PGI-2 were required to inhibit $\left[{ }^{3} \mathrm{H}\right] \mathrm{PGF}-2 \alpha$ binding, indicating a cross-reactivity of $<1 \%$. None of the levels of arachidonic acid tested significantly inhibited the binding of [ $\left.{ }^{3} \mathrm{H}\right] \mathrm{PGF}-2 \alpha$.

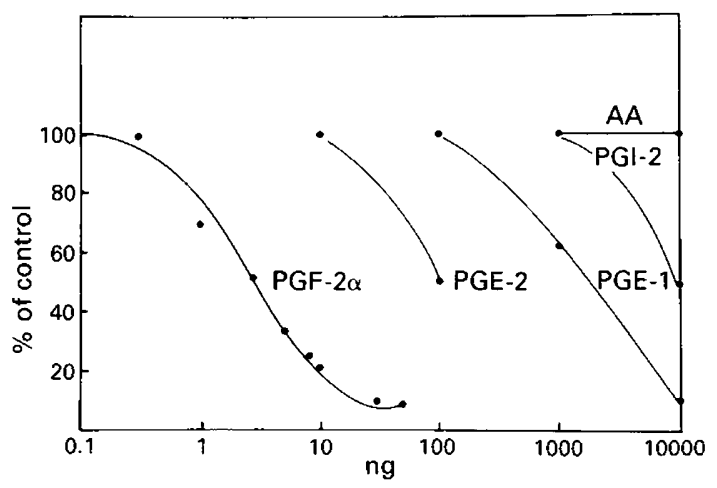

Fig. 1. Inhibition of $\left[{ }^{3} \mathrm{H}\right] \mathrm{PGF}-2 \alpha$ binding to sheep luteal membranes by various prostaglandins and arachidonic acid (AA). 
Scatchard analysis indicated a single class of saturable binding sites for $\left[{ }^{3} \mathrm{H}\right] \mathrm{PGF}-2 \alpha$ (Fig. 2). The affinity of $\left[{ }^{3} \mathrm{H}\right] \mathrm{PGF}-2 \alpha$ binding to ovine luteal membranes averaged $4 \times 10^{8} \mathrm{M}^{-1}$. When different levels of the same tissue pool were analysed by Scatchard analysis, the total number of receptors detected increased with increasing levels of tissue but the concentration of receptors ( $\mathrm{fmol} / \mathrm{mg}$ wet weight of tissue) was constant (data not shown).

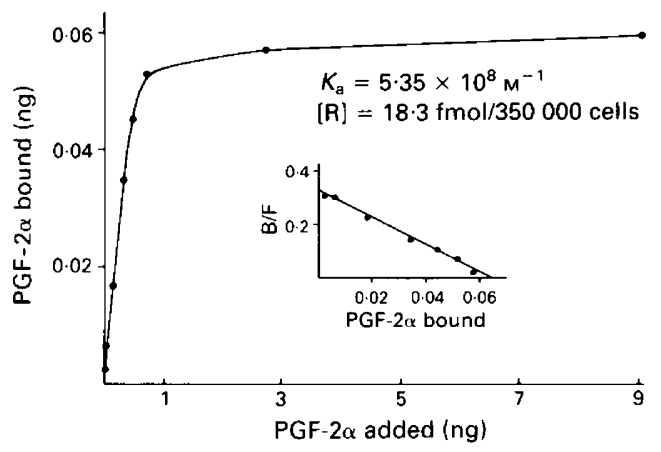

Fig. 2. Saturation and Scatchard analysis of $\left[{ }^{3} \mathrm{H}\right] \mathrm{PGF}-2 \alpha$ binding to sheep luteal membranes.

A comparison of the number of receptors as determined by Scatchard analysis and the standard curve method is presented in Fig. 3. The slope of the regression line was not different from $1(P>0 \cdot 1)$ and the $y$-intercept was not different from $0(P>0 \cdot 1)$. Therefore, the concentration of receptors for PGF- $2 \alpha$ as determined by the standard curve method is similar to that determined by Scatchard analysis. In addition, when plotted, the binding curve obtained from incubating two quantities of sample tissue were parallel to the standard curve, indicating that sample tissue bound $\left[{ }^{3} \mathrm{H}\right] \mathrm{PGF}-2 \alpha$ with the same affinity as did the standard membrane preparation (data not shown).

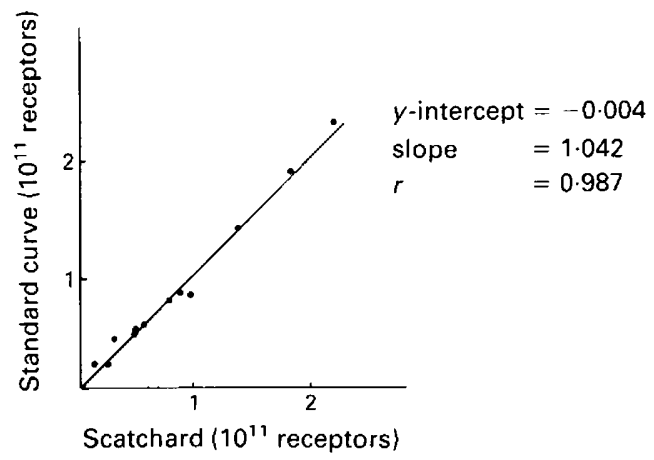

Fig. 3. Comparison of the number of PGF-2 $\alpha$-receptors as determined by Scatchard analysis and the standard curve method.

The limit of detection of the standard curve method for quantification of PGF-2 $\alpha$-receptors was derived from the smallest amount of radiolabelled hormone bound that was on the linear portion of the standard curve and was 8 pmol. The intra-assay coefficient of variation, as determined from replication of the same sample within an assay, was $6 \cdot 2 \%$.

Receptors for $L H$. The concentration of receptors for $\mathrm{LH}$ was also determined by the standard curve technique as described by Braden et al. (1986) except that membranes from mid-cycle ovine corpora lutea were used for the standard membrane preparation. For quantification of receptors for LH in sample tissue, $1 \times 10^{5}$ luteal cells were used in duplicate for each corpus luteum. The limit of detection of LH receptors was $2.5 \mathrm{fmol}$ and the intra-assay coefficient of variation was $2 \cdot 2 \%$. Maximal binding of the ${ }^{125}$ I-labelled hCG was $35 \%$ with $5 \%$ non-specific binding.

Morphometric analysis. For electron microscopy, a single centre slice was taken from each corpus luteum collected on Day 4 and fixed for 4-12 h in a glutaraldehyde solution (4\% glutaraldehyde, $0.1 \mathrm{M}$-cacodylate, $0 \cdot 18 \mathrm{M}$-sucrose; $\mathrm{pH} 7.4)$ at $4^{\circ} \mathrm{C}$. After fixation each slice was cut into 4 equal sized blocks. The glutaraldehyde solution was decanted and blocks of tissues were post-fixed for $90 \mathrm{~min}$ in $1 \% \mathrm{OsO}_{4}-0.1 \mathrm{M}$-cacodylate ( $\mathrm{pH} \mathrm{7.4)}$. The tissue was dehydrated in a graded series of ethanol and embedded in Polybed 812 (Polysciences, Warrington, PA, USA). Thin sections (60$80 \mathrm{~nm}$ ) were cut from each block, stained with uranyl acetate and lead citrate and examined in a JEOL 1200 EX 
electron microscope. Five photographs, taken in a sequential pattern from a randomly selected section of each block, were printed at a final magnification of $\times 4750$. Data were obtained by the point counting method (Wiebel, 1979). A 56-point grid ( $2 \mathrm{~cm}$ between points) on a transparent sheet was placed over each photomicrograph. Counts were registered when a point on the transparent sheet was over a particle of interest (cell, vascular space, extracellular matrix, unidentified component). Point count data were stored using a BioQuant software package ( $R$ and $M$ Biometrics, Nashville, TN, USA). Data regarding nuclei were obtained in the same manner; however, because of the smaller size of nuclei compared to cells, a transparent sheet containing 224 points ( $1 \mathrm{~cm}$ between points) was used.

Point count analysis was used to calculate volume density and the number of nuclei per unit area. The number of cells per unit volume $\left(\mathrm{N}_{\mathrm{v}}\right)$ was calculated using the formula (Wiebel, 1979):

$$
\mathrm{N}_{\mathrm{v}}=\frac{1}{\beta} \cdot \frac{\mathrm{N}_{\mathrm{A}}{ }^{1.5}}{\mathrm{~V}_{\mathrm{v}}{ }^{0.5}}
$$

where $\mathrm{N}_{\mathrm{A}}$ is the number of nuclei of each specific cell type per unit area of the micrograph, $\mathrm{V}_{\mathrm{V}}$ is the volume density of nuclei (the total of the area of all nuclei from a particular cell type divided by the total area of the micrograph), and $\beta$ is a correction factor based on the shape of nuclei. Rodgers et al. (1984) previously reported values for $\beta$ of 1.382 for small and large luteal cells, 1.9 for capillary endothelial cells and pericytes and 1.7 for fibroblasts. The mean number of each type of cell per unit volume was calculated from the sum of all 4 blocks and not the mean of each block. The number of cells of each specific type per corpus luteum was the product of the number of cells per unit volume and the total volume of the corpus luteum. Mean cell volume was calculated as the volume density of each specific cell type divided by the total number of cells of that type per unit volume. Mean cell diameter was calculated assuming that all cells had a spherical shape (volume $=[4 / 3] \pi \mathrm{r}^{3}$ ). All data from each tissue block were corrected for shrinkage due to fixation to $92 \%$ of the original size. This figure was based on a comparison of measurements from fresh tissue blocks taken before and after the fixation and embedding procedures.

The criteria used to identify the major cell types in the corpus luteum (large and small luteal cells, fibroblasts, capillary endothelial cells and pericytes) were as previously described by Rodgers et al. (1984), Niswender et al. (1985) and Farin et al. (1986). Extracellular matrix was defined as the non-cellular material between luteal cells, whereas 'other' refers to tissue components that could not be positively classified into one of the categories.

Statistical analyses. Data regarding progesterone production in vitro were analysed using a paired $t$ test comparing progesterone secretion in the presence and absence of oLH for each corpus luteum. Analysis of variance was initially used to identify significant differences between groups in concentrations of receptors for PGF-2 $\alpha$. Differences between Groups $\mathrm{F}$ and $\mathrm{C}$ for all other parameters were tested through the use of Student's $t$ test (Steele \& Torrie, 1980).

\section{Results}

There was no difference in the mass of corpora lutea from ewes in Groups F and C on Day 4 $(214 \pm 10$ vs $214 \pm 7 \mathrm{mg}$, respectively; mean \pm s.e.). By Day 7 , corpora lutea from Group $F$ weighed less than those from Group C ( $280 \pm 80 \mathrm{vs} 465 \pm 25 \mathrm{mg}$, respectively, $P<0.01)$.

There was no difference in the quantities of progesterone secreted in vitro by cells from corpora lutea collected on Days 4 and 7 from Group $\mathrm{F}$ or $\mathrm{C}$ ewes and data from both days were combined for further analysis. Luteal cells from Group $C$ ewes secreted more progesterone $(P<0.05)$ in the absence or presence of $100 \mathrm{ng} \mathrm{oLH} / \mathrm{ml}$ than did those from Group F (Fig. 4).

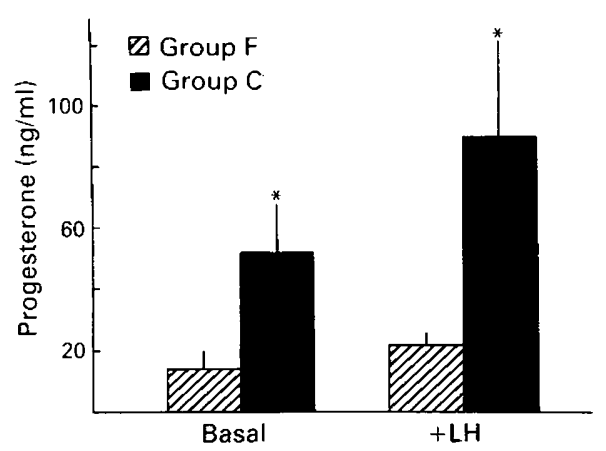

Fig. 4. Effect of LH on in-vitro secretion of progesterone by luteal cells obtained from ewes in Groups $F$ and $C$. Values are mean \pm s.e.m. for the number of observations indicated in text. ${ }^{*} P<0.05$. 
On Day 4 there was a tendency for there to be fewer receptors for $\mathrm{LH}$ in luteal cells of Group $\mathrm{F}$ compared to Group C $(P<0 \cdot 1$; Fig. 5a) but by Day 7 there was no difference $(P>0 \cdot 1)$. Likewise, there was a tendency for fewer receptors for PGF- $2 \alpha$ in luteal cells of Group F compared to Group $\mathrm{C}(P<0 \cdot 1)$ on Day 4 ; however, by Day 7 this difference was not significant $(P>0 \cdot 1$; Fig. 5b).
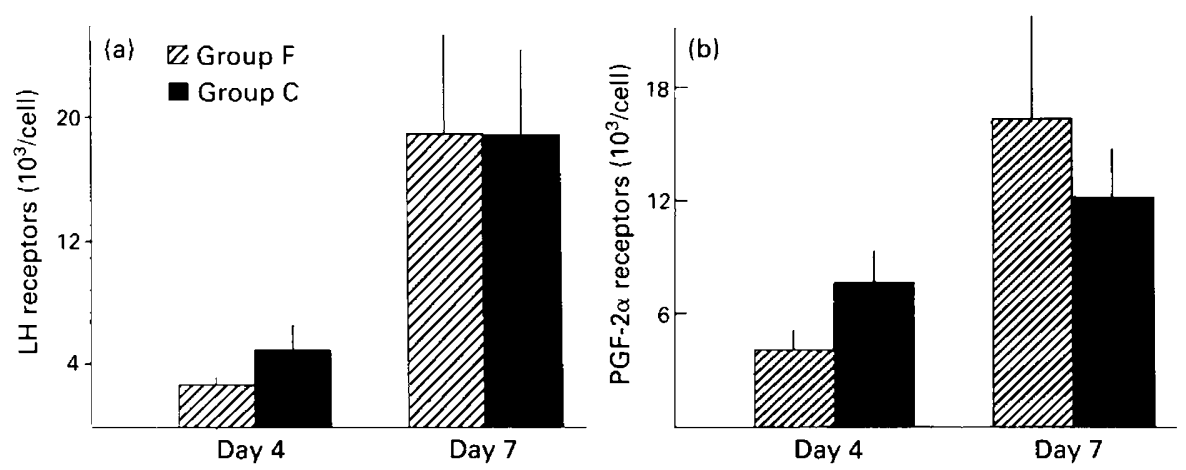

Fig. 5. Effect of LH on concentrations of receptors for (a) LH and (b) PGF-2 $\alpha$ in luteal cells obtained from ewes in Groups $F$ and $C$. Values are mean \pm s.e.m. for the number of observations indicated in text. ${ }^{*} P<0 \cdot 05$.

The volume density of luteal components is presented in Table 1 . There were no differences identified between corpora lutea from Group F and Group C ewes. Approximately $40 \%$ of the volume comprised large and small luteal cells. Fibroblasts occupied approximately $16 \%$ of the corpora lutea while vascular components accounted for $12 \%$. The extracellular matrix accounted for $32 \%$ of the volume of corpora lutea from ewes in Groups F and C and $1 \%$ of the volume was occupied by unidentified cells and cellular debris.

Table 1. Volume density (\%) of luteal tissue components

\begin{tabular}{lrr}
\hline Component & Group F & Group C \\
\hline Steroidogenic cells* & $42 \pm 1$ & $39 \pm 2$ \\
$\quad$ Large luteal & $21 \pm 2$ & $21 \pm 3$ \\
Small luteal & $20 \pm 3$ & $18 \pm 4$ \\
Fibroblasts & $16 \pm 1$ & $15 \pm 3$ \\
Capillaries & $11 \pm 2$ & $12 \pm 2$ \\
CE/P† & $10 \pm 1$ & $10 \pm 2$ \\
$\quad$ Luminal space & $2 \pm 0$ & $2 \pm 1$ \\
Extracellular matrix & $30 \pm 1$ & $33 \pm 3$ \\
Other & $1 \pm 0$ & $1 \pm 0$ \\
\hline
\end{tabular}

Values are mean \pm s.e.; $N=5 /$ group.

*Based on morphological criteria.

†Capillary endothelial cells and pericytes.

No significant difference was detected between Groups $F$ and $C$ for the total number of any specific cell type (Table 2). Based on morphological criteria, approximately one-third of the cells in these corpora lutea were steroidogenic large and small luteal cells. The total number of luteal cells per corpus luteum was approximately $107 \times 10^{6}$. The mean cell diameter (as calculated from the mean cell volume) of the populations of specific cell types in the corpus luteum (Table 3 ) did not differ between Groups $\mathbf{F}$ and $\mathrm{C}$. 
Table 2. Number of cells per corpus luteum $\left(\times 10^{-6}\right)$

\begin{tabular}{lrr}
\hline Cell type & Group F & Group C \\
\hline Steroidogenic cells* & $34 \pm 5$ & $28 \pm 4$ \\
$\quad$ Large luteal & $13 \pm 2$ & $11 \pm 3$ \\
Small luteal & $21 \pm 5$ & $18 \pm 3$ \\
Fibroblasts & $35 \pm 5$ & $43 \pm 11$ \\
CE/P $\dagger$ & $34 \pm 4$ & $43 \pm 15$ \\
Total & $103 \pm 7$ & $115 \pm 21$ \\
\hline
\end{tabular}

Values are mean \pm s.e.; $N=5$ /group.

*Based on morphological criteria.

†Capillary endothelial cells and pericytes.

Table 3. Mean cell diameter of luteal cell types $(\mu \mathrm{m})$

\begin{tabular}{lcc}
\hline Cell type & Group F & Group C \\
\hline Steroidogenic cells* & $19 \pm 1$ & $20 \pm 2$ \\
$\quad$ Large luteal & $17 \pm 2$ & $15 \pm \mathrm{I}$ \\
Small luteal & $12 \pm 0$ & $13 \pm 1$ \\
Fibroblasts & $11 \pm 0$ & $10 \pm 0$ \\
CE/P† & \\
\hline
\end{tabular}

Values are mean \pm s.e.; $N=5 /$ group.

*Based on morphological criteria.

†Capillary endothelial cells and pericytes.

\section{Discussion}

The observation that corpora lutea from Group $F$ ewes on Day 7 weighed less than those from Group $C$ ewes on Day 7 provides evidence that corpora lutea of Group F ewes were destined to be short-lived. In addition, 3 corpora lutea from Group F ewes on Day 7 were pale in colour and appeared to be in the early stages of luteolysis.

Although progesterone production in vitro by luteal cells from Group $F$ was significantly less than that by luteal cells from Group $\mathrm{C}$, there was no difference in the concentration of receptors for LH between the two groups. In other studies, the administration of LH or human chorionic gonadotrophin had no effect (Kesler et al., 1981; McNeilly et al., 1981) or stimulated (O'Shea et al., 1984; Duby et al., 1985; Rutter et al., 1985) the secretion of progesterone in vitro from corpora lutea expected to be short-lived. Additionally, no differences in the concentration of receptors for $\mathrm{LH}$ have been identified between corpora lutea expected to have short or normal lifespans (McNeilly et al., 1981; Rutter et al., 1985; Smith et al., 1986) as found in the present study. Therefore, decreased secretion of progesterone by luteal cells of Group $F$ ewes may be the result of a deficient coupling mechanism between binding of $\mathrm{LH}$ to receptor and secretion of progesterone. Smith et al. (1986) reported higher levels of phosphodiesterase activity in the first corpus luteum formed after parturition compared to subsequently formed corpora lutea in cows.

One of the first effects of administration of PGF-2 $\alpha$ on luteal cells is the inactivation of LHsensitive adenylate cyclase (Fletcher \& Niswender, 1982). It is therefore possible that corpora lutea of Group F ewes were in the early stages of regression by the time they were collected and LHsensitive adenylate cyclase was already reduced. This could explain why LH did not stimulate 
progesterone secretion in luteal cells from Group F ewes even though there was no shortage of LH receptors.

This is the first report of morphometric analysis of cell types in spontaneously formed sheep corpora lutea expected to have a shortened life-span. There was no difference in the number of large or small luteal cells between GnRH-treated ewes and cyclic control ewes (O'Shea et al., 1984). However, small luteal cells from GnRH-treated ewes were smaller than those in cyclic control ewes. Similarly, there was no difference in the number of large luteal cells in bovine corpora lutea collected after the first post-partum ovulation when compared to corpora lutea from subsequent oestrous cycles (Duby et al., 1985). In contrast, Manns et al. (1983) reported that some bovine corpora lutea, expected to be short-lived, had a greater number of large luteal cells. Again, this observation was not consistent for all animals expected to have a short luteal phase. Rutter et al. (1985), using dissociated cells, could not identify any difference in the cellular composition of the first corpus luteum formed after parturition compared to corpora lutea from normal cyclic animals. However, this characterization was performed at the light microscopic level and no effort was made to identify steroidogenic cell types. Therefore, their data could have been confounded by the presence of small non-steroidogenic cells (i.e. capillary endothelial cells and fibroblasts) as well as of large luteal cells of small size as reported by Farin et al. (1986).

The results of the present study indicated no difference in the cellular composition of corpora lutea expected to have a shortened life-span and those expected to have a normal life-span. Therefore, although preovulatory follicles expected to result in short-lived corpora lutea in cows contained more granulosa cells than subsequently formed preovulatory follicles (Braden et al., 1989), this does not result in a short-lived corpus luteum with an increased proportion of large luteal cells. However, data from preovulatory follicles were obtained from cows (Braden et al., 1989) while the present study was conducted in ewes and so species differences cannot be excluded.

In summary, although cells obtained from short-lived corpora lutea were less responsive to $\mathrm{LH}$, they had normal numbers of receptors for this hormone. In addition, no evidence was obtained to indicate that cells from short-lived corpora lutea had increased numbers of receptors for PGF-2 $\alpha$ or that these corpora lutea had increased numbers of large luteal cells. The results of this experiment are consistent with those of Copelin et al. (1988) who did not identify an enhanced luteolytic effect of PGF- $2 \alpha$ administered to cows expected to have a short luteal phase. Therefore, we conclude that, if corpora lutea with a shortened life span are more sensitive to the luteolytic effects of PGF-2 $\alpha$, this effect is not the result of a greater number of receptors for PGF-2 $\alpha$ or an enhanced proportion of large luteal cells.

Supported by the Colorado State University Agricultural Experiment Station and a grant from the National Institutes of Health (HD1 1590).

\section{References}

Alila, H.W. \& Hansel, W. (1984) Origin of different cell types in the bovine corpus luteum as characterized by specific monoclonal antibodies. Biol. Reprod. 31, $1015-1025$.

Berardinelli, J.G., Dailey, R.A., Butcher, R.L. \& Inskeep, E.K. (1979) Source of progesterone prior to puberty in beef heifers. J. Anim. Sci. 49, 1276-1280.

Berardinelli, J.G., Dailey, R.A., Butcher, R.L. \& Inskeep, E.K. (1980) Source of circulating progesterone in prepubertal ewes. Biol. Reprod. 22, 233-236.

Braden, T.D., Manns, J.G., Cermak, D.L., Nett, T.M. \& Niswender, G.D. (1986) Follicular development following parturition and during the estrous cycle in beef cows. Theriogenology 25, 833-843.

Braden, T.D., King, M.E., Odde, K.G. \& Niswender, G.D.
(1989) Development of preovulatory follicles destined to form short-lived corpora lutea in beef cows. J. Reprod. Fert. 85, 97-104.

Carruthers, T.D., Manns, J.G. \& Rutter, L.M. (1986) Failure of human chorionic gonadotropin injections to sustain gonadotropin-releasing hormone-induced corpora lutea in post partum beef cows. Biol. Reprod. $35,846-849$.

Copelin, J.P., Smith, M.F., Garverick, H.A. \& Youngquist, R.S. (1987) Effect of the uterus on subnormal luteal function in anestrous beef cows. J. Anim. Sci. 64, 1506-1511.

Copelin, J.P., Smith, M.F., Garverick, H.A., Youngquist, R.S., McVey, W.R., Jr \& Inskeep, E.K. (1988) Responsiveness of bovine corpora lutea to prosta- 
glandin $\mathrm{F}_{20}$ : comparison of corpora lutea anticipated to have a short or normal lifespan. J. Anim. Sci. 66, 1236-1245.

Donaldson, L. \& Hansel, W. (1965) Histological study of bovine corpora lutea. J. Dairy Sci. 48, 905-909.

Duby, R.T., Browning, R., Carey, D. \& Black, D.L. (1985) Progesterone synthesis and histology of post partum bovine corpora lutea. Theriogenology 23, 619-630.

Farin, C.E., Moeller, C.L., Sawyer, H.R., Gamboni, F. \& Niswender, G.D. (1986) Morphometric analysis of cell types in the ovine corpus luteum throughout the estrous cycle. Biol. Reprod. 35, 1299-1308.

Fitz, T.A., Mayan, M.H., Sawyer, H.R. \& Niswender, G.D. (1982) Characterization of two steroidogenic cell types in the ovine corpus luteum. Biol. Reprod. 27, 703-711.

Fletcher, P.W. \& Niswender, G.D. (1982) Effect of PGF on progesterone secretion and adenylate cyclase activity in ovine luteal tissue. Prostaglandins 23, 803-818.

Gonzalez-Padilla, E., Ruiz, R., LeFever, D., Denham, A. \& Wiltbank, J.N. (1975) Puberty in beef heifers. III. Induction of fertile estrus. J. Anim. Sci. 40, $1110-1118$.

Kesler, D.J., Weston, P.G., Pimental, C.A., Troxel, T.R., Vincent, D.L. \& Hixon, J.E. (1981) Diminution of the in vitro response to luteinizing hormone by corpora lutea induced by gonadotropin releasing hormone treatment of post partum suckled beef cows. J. Anim. Sci. 53, 749-754.

Lamming, G.E., Wathes, D.C. \& Peters, A.R. (1981) Endocrine patterns of the post partum cow. $J$. Reprod. Fert., Suppl. 30, 155-170.

Manns, J.G., Humphrey, W.D., Flood, P.F., Mapletoft, R.J., Rawlings, N.C. \& Cheng, K.W. (1983) Endocrine profiles and functional characteristics of corpora lutea following onset of post partum ovarian activity in beef cows. Can. J. Anim. Sci. 63, 331-347.

McClellan, M.C., Diekman, M.A., Abel, J.H., Jr \& Niswender, G.D. (1975) LH, progesterone and the morphological development of normal and superovulated corpora lutea in sheep. Cell Tiss. Res. 164, 291-307.

McNeilly, A.S., Hunter, M., Land, R.B. \& Fraser, H.M. (1981) Inadequate corpus luteum function after the induction of ovulation in anoestrous ewes by LH-RH or an LH-RH antagonist. J. Reprod. Fert. 63, 137-144.

Nett, T.M., Crowder, M.E., Moss, G.E. \& Duello, T.M. (1981) GnRH-receptor interaction. V. Down regulation of pituitary receptors for GnRH in ovariectomized ewes by infusion of homologous hormone. Biol. Reprod. 24, 1145-1155.

Niswender, G.D. (1973) Influence of the site of conjugation on specificity of antibodies to progesterone. Steroids 22, 413-424.

Niswender, G.D., Reichert, L.E., Jr, Midgley, A.R., Jr \& Nalbandov, A.V. (1969) Radioimmunoassay for bovine and ovine luteinizing hormone. Endocrinology 84, $1166-1173$.

Niswender, G.D., Schwall, R.H., Fitz, T.A., Farin, C. \& Sawyer, H.R. (1985) Regulation of luteal function in domestic ruminants: new concepts. In Recent Progress in Hormone Research, Vol. 41, pp. 101-142. Ed. R. O. Greep. Academic Press, New York.

O'Shea, J.D., Rodgers, R.J. \& Wright, P.J. (1984) Morphometric analysis and function in vitro and in vivo of corpora lutea from ewes treated with LHRH during seasonal anoestrus. J. Reprod. Fert. 72, 75-85.

Rodgers, R.J., O'Shea, J.D. \& Bruce, N.W. (1984) Morphometric analysis of cellular composition of the ovine corpus luteum. J. Anat. 138, 757-769.

Rutter, L.M., Carruthers, T.D. \& Manns, J.G. (1985) The postpartum induced corpus luteum: functional differences from that of cycling cows and the effects of progesterone pretreatment. Biol. Reprod. 33, 560-568.

Scatchard, G. (1949) The attractions of proteins for small molecules and ions. Ann. N.Y. Acad. Sci. 51, 660672 .

Schirar, A. \& Martinet, J. (1982) Post partum ovarian activity and its interaction with the uterus in resuming cyclic activity post partum. In Factors Influencing Fertility in the Post Partum Cow, pp. 67-94. Eds H. Karg \& E. Schallenberg. Martinus Nijoff, Boston.

Simmons, K.R., Caffrey, J.L., Phillips, J.L., Abel, J.H., Jr \& Niswender, G.D. (1976) A simple method for preparing suspensions of luteal cells. Proc. Soc. exp. Biol. Med. 152, 366-371.

Smith, M.F., Garverick, H.A., Youngquist, R.S. \& Zahler, W.L. (1986) Luteinizing hormone receptor concentrations, adenylate cyclase and phosphodiesterase activity of bovine corpora lutea: comparison of short and normal estrous cycle. Dom. Anim. Endocrinol. 3, 127-133.

Steele, R.G.D. \& Torrie, J.H. (1980) Principles and Procedures of Statistics: a Biometrical Approach, 2nd edn. McGraw-Hill, New York.

Thatcher, W.W., Wilcox, C.J., Collier, R.J., Eley, D. \& Head, H. (1980) Bovine conceptus-maternal interaction during pre- and postpartum periods. J. Dairy Sci. 63, 1530-1540.

Troxel, T.R. \& Kesler, D.J. (1984a) Ability of indomethacin to alter prostaglandin metabolite concentrations and to enhance the function of corpora lutea in induced post partum suckled beef cows. J. Anim. Sci. 59, 177-181.

Troxel, T.R. \& Kesler, D.J. (1984b) The effect of progestin and GnRH treatments on ovarian function and reproductive hormone secretions of anestrous post partum beef cows. Theriogenology 21, 699-711.

Wiebel, E.R. (1979) Stereological Methods. Vol. I. Practical Methods for Biological Morphometry. Academic Press, London.

Wise, M.E., Glass, J.D. \& Nett, T.M. (1986) Changes in the concentration of hypothalamus and hypophyseal receptors for estradiol in pregnant and post partum ewes. J. Anim. Sci. 62, 1021-1028.

Yuthasastrakosol, P., Palmer, W.M. \& Howland, B.E. (1975) Luteinizing hormone, oestrogen and progesterone levels in peripheral serum of anoestrous and cyclic ewes as determined by radioimmunoassay. J. Reprod. Fert. 43, 57-65.

Received 28 September 1988 